\title{
Ergonomic tool: A way to assess musculoskeletal problems faced by children due to carrying of school bags
}

See end of the paper for authors' affiliations K. PANT

College of Home Science, Punjab Agricultural University, LUDHIANA (PUNJAB) INDIA

\begin{abstract}
School children are adolescents who experience a period of accelerated growth and development of skeletal and soft tissue. The spinal structures of the child are markedly different from those of adults. As growth of the spinal structures extends over a longer period of time than the other skeletal tissues, incongruities in rate of tissue development can pose a threat to postural integrity. The present study was conducted to assess musculoskeletal problems faced by children due to carrying of school bag by using ergonomic tool i.e. Standardized Nordic Musculoskeletal Questionnaire. The suggestions of the parents were also taken in this regard. The study was conducted on a sample of 120 school children from middle class (i.e. from vi to viii) and their mothers. Respondents were randomly selected from five government and five private schools of Ludhiana city form the age group of 11-14 years. A pre structured interview schedule was used to collect the data along with Standardized Nordic Musculoskeletal Questionnaire. Results showed that neck, shoulder and upper/lower back had significantly more problems than other body parts. It was further observed that maximum number of parents wanted that school authority should make judicious time table and lockers should be provided to avoid unnecessary loading of school bags. Moreover, need to conduct lectures on maintenance of good posture among school children was also felt by parents
\end{abstract}

KEY WORDS: Ergonomic tool, Musculoskeletal problem, School bags

- HOW TO CITE THIS PAPER : Pant, K., Kaur, H. and Sidhu, M. (2016). Ergonomic tool: A way to assess musculoskeletal problems faced by children due to carrying of school bags. Asian J. Home Sci., 11 (1) : 48-51, DOI: 10.15740/HAS/AJHS/11.1/48-51. 